\title{
THE PROFILE OF POTT'S DISEASE IN A SOUTH AMERICAN REFERENCE SERVICE
}

\author{
PERFIL DO MAL DE POTT EM UM SERVIÇO DE REFERÊNCIA SUL-AMERICANO
}

\author{
PERFIL DE LA ENFERMEDAD DE POTT EN UN SERVICIO DE REFERENCIA SUDAMERICANO

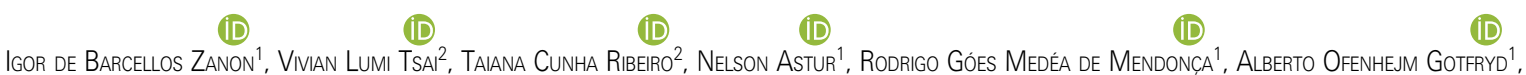 \\ Mauro José Costa Salles ${ }^{2}$, Maria Fernanda Silber Caffaro ${ }^{1}$, Giselle Burlamadui Klautau ${ }^{2}$, Robert Meves ${ }^{1}$
}

1. Santa Casa de Misericórdia de São Paulo, Department of Orthopedics and Traumatology, Pavilhão Fernandinho Simonsen, Spinal Disorders Group, São Paulo, SP, Brazil. 2. Santa Casa de Misericórdia de São Paulo, Department of Clinical Medicine, Infectology Unit, São Paulo, SP, Brazil.

\begin{abstract}
Objective: Tuberculosis (TB) represents one of the top ten causes of death in the world. Its insidious onset and nonspecific symptoms usually result in delayed diagnosis. The objective is to evaluate the characteristics of patients with tuberculous spondylodiscitis in follow-up at a South American reference hospital. Method: Retrospective evaluation of the medical records of patients of both sexes and between 0 and 80 years of age diagnosed with tuberculosis of the spine between 2009 and 2018. The variables were analyzed based on groups: epidemiological, clinical, laboratorial, microbiological, imaging tests and treatment. Results: Total of 26 cases, about $80.8 \%$ male, mean age $41.6 \pm 22.46$ years. Axial pain was the most prevalent symptom (84.6\%), the VAS score was $6.85 \pm 2.87$. The mean time between symptom onset and diagnosis was $23.8 \pm 24.1$ weeks (4-96). The most affected region was the thoracic spine (50\% of the cases). Most participants (61.4\%) had no change in neurological function (Frankel D and E) at the beginning of treatment and after 6 months, and $84.5 \%$ improved. During treatment $34.6 \%$ required surgery and the main indication was isolated neurological deficit (55.5\%). The most frequently performed procedure was decompression and arthrodesis (55.5\%). The average time to cure was $12.0 \pm 8.8$ months (8-48). Conclusion: Disease with insidious onset, nonspecific symptoms, high frequency of negative microbiological tests in cases with the disease. A small number of the cases required surgical treatment and most of them achieved good neurological recovery. Level of evidence IV; Case series.
\end{abstract}

Keywords: Tuberculosis; Spine; Diagnosis.

\section{RESUMO}

Objetivo: A tuberculose (TB) é uma das dez principais causas de morte no mundo. O início insidioso e os sintomas inespecíficos geralmente resultam em atraso do diagnóstico. O objetivo é avaliar as características dos pacientes com espondilodiscite tuberculosa em acompanhamento, em um hospital de referência sul-americano. Método: Avaliação retrospectiva de dados de prontuários, diagnóstico de tuberculose da coluna vertebral entre 2009 e 2018, de ambos os sexos, entre 0 e 80 anos de idade. As variáveis foram analisadas com base em grupos: epidemiológicas, clínicas, laboratoriais, microbiológicas, exames de imagem e tratamento. Resultados: Total de 26 casos, cerca de 80,8\% do sexo masculino, média de idade de 41,6 $\pm 22,46$ anos. A dor axial foi o sintoma mais prevalente (84,6\%), o escore da EVA foi de 6,85 $\pm 2,87$. A média de tempo entre o início dos sintomas e o diagnóstico foi de $23,8 \pm 24,1$ semanas (4-96). A região mais acometida foi a coluna torácica (50\% dos casos). A maioria (61,4\%) dos participantes apresentou função neurológica inalterada (Frankel $D$ e E) no início do tratamento e 6 meses depois, sendo que 84,5\% obtiveram melhora. No tratamento, 34,6\% necessitaram de cirurgia, e a principal indicação foi déficit neurológico isolado (55,5\%). O procedimento mais realizado foi descompressão e artrodese (55,5\%). 0 tempo médio até a cura foi de 12,0 \pm 8,8 meses (8-48). Conclusão: Doença de início insidioso, sintomas inespecíficos, grande frequência de exames microbiológicos negativos em casos com a doença. A menor parte dos casos necessitou de tratamento cirúrgico e a maioria apresentou boa recuperação neurológica. Nível de evidência IV; Série de casos.

Descritores: Tuberculose; Coluna Vertebral; Diagnóstico.

\section{RESUMEN}

Objetivo: La tuberculosis (TB) es una de las diez principales causas de muerte en el mundo. El inicio insidioso y los síntomas inespecíficos generalmente resultan en atraso del diagnóstico. El objetivo es evaluar las características de los pacientes con espondilodiscitis tuberculosa en acompañamiento en un hospital de referencia sudamericano. Método: Evaluación retrospectiva de datos de historiales clínicos, diagnóstico de tuberculosis de la columna vertebral entre 2009 y 2018, de ambos sexos, entre 0 y 80 años de edad. Las variables fueron analizadas con base en grupos: epidemiológicas, clínicas, de laboratorio, microbiológicas, exámenes de imagen y tratamiento. Resultados: Total de 26 casos, cerca de 80,8\% del sexo masculino, promedio de edad de 41,6 $\pm 22,46$ años. El dolor axial fue el síntoma más prevalente (84,6\%). El puntaje de la EVA fue de 6,85 $\pm 2,87$. El promedio de tiempo entre el inicio de los síntomas y el diagnóstico fue de 23,8 $\pm 24,1$ semanas (4-96). La región más acometida fue la columna torácica (50\% de los casos). La mayoría (61,4\%) de los participantes

Study conducted at the Santa Casa de Misericórdia de São Paulo, Department of Orthopedics and Traumatology, Pavilhão Fernandinho Simonsen, Spinal Disorders Group, São Paulo, SP, Brazil.

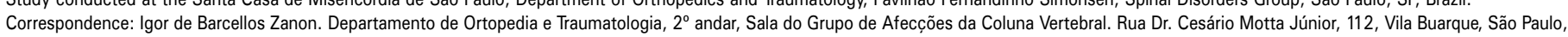
SP, Brasil. 01221-020. igorzanon@gmail.com 
presentó función neurológica inalterada (Frankel D y E) al inicio del tratamiento y seis meses después, siendo que 84,5\% obtuvo mejora. En el tratamiento, 34,6\% precisó cirugía, y la principal indicación fue déficit neurológico aislado, $(55,5 \%)$. El procedimiento más realizado fue descompresión y artrodesis (55,5\%). El tiempo promedio hasta la cura fue de 12,0 \pm 8,8 meses (8-48). Conclusión: Enfermedad de inicio insidioso, síntomas inespecíficos, alta frecuencia de exámenes microbiológicos negativos en casos con la enfermedad. La menor parte de los casos requirió tratamiento quirúrgico y la mayoría presentó buena recuperación neurológica. Nivel de evidencia IV; Serie de casos.

Descriptores: Tuberculosis; Columna Vertebral; Diagnóstico.

\section{INTRODUCTION}

Tuberculosis (TB) is a global public health issue with high morbidity, and it is one of the main causes of death in the world. ${ }^{1}$ In 2016 , the World Health Organization estimated around 10 million new cases per year. ${ }^{2}$ It predominates in underdeveloped countries and is related to poverty, malnutrition, immunosuppression, and HIV infection. ${ }^{3}$ Spinal TB was first described by Sir Percival Pott in 1779 as a disease that involved destruction of the spine, paraplegia and increased thoracic kyphosis. The causative agent, Mycobacterium tuberculosis, was isolated more than a century later by Robert Koch. ${ }^{4,5}$

It is the main site of osteoarticular involvement in TB, occurring in about $50 \%$ of cases, and it accounts for $1 \%$ of all cases. ${ }^{6}$ The insidious onset and non-specific symptoms usually result in a delayed diagnosis, varying from 4 to 11 months from the onset of symptoms. ${ }^{7}$

Axial pain is the most common symptom, but weight loss, fatigue, malaise, night sweats, fever are also observed, as well as neurological deficit in the more advanced phase. ${ }^{8-10}$ In children, the signs and symptoms also are non-specific, such as torticollis, claudication, pain, and palpable mass. ${ }^{4}$ Increases in leukocytes, C-reactive protein and erythrocyte sedimentation rate are observed in the laboratory examinations. ${ }^{11}$

Diagnosis is made through clinical and radiological characteristics, isolation of the microbiological agent using bacilloscopy, culture or the rapid molecular test for TB (RMT-TB), and/or anatomopathological testing and/or a positive therapeutic test. Biopsy guided by computed tomography (CT) is the gold-standard method for microbiological sample collection. ${ }^{12}$ In the anatomopathological examination, the use of hematoxylin-eosin staining allows the identification of granuloma with caseous necrosis and in bacilloscopy, Ziehl-Neelsen staining assists in the search for alcohol-acid resistant bacilli. ${ }^{2,8}$ Culture is considered the gold standard for diagnosis. Since 2013, the WHO has recommended the use of RMT-TB in suspected cases of extrapulmonary tuberculosis, using the real-time polymerase chain reaction technique. Only one sample is needed, and results are obtained in 2 hours. $^{8}$

The initial radiographs showed radiolucency and loss of definition of the vertebral endplates, and endplate erosion, loss of disc height, vertebral geodes, bone sequestration and destruction of the vertebral body - predominantly anterior with collapse and increased local kyphosis - were observed in subsequent phases. Computed tomography (CT) allows better evaluation of the characteristics seen in radiographs and also identification of paravertebral calcifications, which are highly suggestive of TB. ${ }^{10}$ Magnetic Resonance is the imaging examination of choice for diagnosis. Due to its high sensitivity and specificity, it helps in the early detection of bone and disc involvement, non-contiguous lesions, anterior subligamentous dissemination, and epidural, pre- and paravertebral, and psoas muscle abscesses. The affected vertebral bodies exhibit hyposignal in T1-weighted sequences and hypersignal in T2 and STIR sequences. The intervertebral disc exhibits hypersignal in T2. In doubtful cases, the use of gadolinium as a contrast helps to show a clearer hypersignal in the affected areas. ${ }^{10}$ The disease usually involves two vertebral bodies and the disc between them, but the involvement of 3 or more levels is not uncommon. ${ }^{10}$ The thoracic spine is the most affected region. ${ }^{13,14}$

Pharmacological therapy is the main form of treatment, surgery being reserved for cases that require abscess debridement or that involve instability and neurological deficit. ${ }^{8}$ The prognosis is directly related to early diagnosis and institution of treatment. ${ }^{15}$ The objective of this study is to evaluate the characteristics of patients with tuberculous spondylodiscitis in follow-up at a South American reference hospital.

\section{METHODS}

The study was approved by the Institutional Review Board of the institution where it was conducted as CAAE number 92596718.2.0000.5479. Being a retrospective study, the Informed Consent Form was only presented to patients who were being treated at the institution during the period that the research was being conducted. The retrospective evaluation was conducted from the medical records of patients of both sexes, from 0 to 80 years of age, who were diagnosed with spinal tuberculosis and participated in follow-up at the institution between 2009 and 2018.

A diagnosis of TB was considered for patients with clinical characteristics and characteristic imaging examinations, plus at least one of the following criteria: isolation of the etiological agent, compatible anatomopathological examination or positive therapeutic test. ${ }^{8}$ Patients with non-tuberculosis spondylodiscitis or incomplete medical records or imaging examination were excluded. The variables were analyzed based on previous studies that related these factors to the disease under study and which, at the suggestion of the author, were divided into groups: epidemiological, clinical, laboratorial, microbiological, imaging examinations, and treatment. Epidemiological: age, sex, presence of factors related to immunosuppression (diabetes mellitus, chronic kidney disease, prolonged previous use of corticosteroid therapy (more than 6 months), HIV infection and active neoplasia), poverty-related (homelessness), the presence of pulmonary tuberculosis and contact with cases of tuberculosis. ${ }^{8}$ Clinical: pain, the visual analog scale (VAS) of pain at the time of diagnosis, neurological status (Frankel scale at the time of diagnosis and at 6 months), respiratory symptoms (dyspnea or cough), constitutional symptoms (weight loss, loss of appetite and night sweats), fever (temperature equal to or higher than 37.8 degrees Celsius) and time from symptom onset to diagnosis (in months). ${ }^{16-18}$ Laboratorial: leukocytes, monocyte/lymphocyte ratio, C-reactive protein and erythrocyte sedimentation rate. ${ }^{11,19-21}$ Imaging tests: number of affected levels, multiple levels, non-contiguous levels, location (cervical, thoracic, thoracolumbar transition and lumbar - we considered lesions in more than one region, as is the case with non-contiguous lesions, as more than one). ${ }^{10,22,23}$ Microbiological: anatomopathological (hematoxylin-eosin staining, presence of granuloma with caseous necrosis), bacilloscopy (Ziehl-Neelsen staining, alcohol-acid resistant bacilli research), culture (Löwenstein-Jensen medium) and RMT-TB (GeneXpert MTB/RIF method). Treatment: Biopsy performed, type of biopsy (conventional - open, transpedicular, or CT-guided), need for surgical procedure, indication (collection of material for microbiological examination, neurological deficit, instability, deformity and instability associated with deformity), type of procedure (abscess drainage, costotransversectomy/ Carpener, decompression and arthrodesis), instrumentation, cure time (in months) and complications (neurological deficit, chronic pain, infection of the surgical site and death). ${ }^{16,17}$ There is no consensus among studies on the topic around the definition of instability. In this study, it was defined considering the opinions of three specialists with more than 10 years of experience in spine surgery based on the following criteria: segmental kyphosis greater than 30 degrees and compromise of more than $50 \%$ of the vertebral body. Statistical analysis: For descriptive analysis, the qualitative variables 
were described as frequencies (number and percentages) and the quantitative variables as summary measurements (mean, standard deviation, minimum and maximum). The data obtained underwent statistical analysis using Microsoft Excel for Macintosh, version 16.33 software (Microsoft Inc., Redmond, WA, USA).

\section{RESULTS}

Twenty-six patients treated by the institution between 2009 and 2018 with a diagnosis of spinal tuberculosis were identified. Of these, 21 were males with a mean age of $41.6 \pm 22.46$ years (2-77). Among the factors related to immunosuppression, diabetes mellitus was the most prevalent (15.3\%). (Table 1) Axial pain was the most frequent symptom (84.6\%), with a mean VAS of $6.85 \pm 2.87$, followed by constitutional symptoms (54\%), respiratory symptoms (34.6\%) and fever $(30.7 \%)$. The mean time between the onset of symptoms and diagnosis was $23.8 \pm 24.1$ weeks (4-96). (Table 2) Regarding laboratory tests, mean leukocytes were $7.9 \pm 2.3 \times 1000 / \mathrm{ml}$; the mean monocyte/lymphocyte ratio was $0.58 \pm 0.49(0.13-2.44)$ with a median of 0.46 ; the mean CRP was $5.5 \pm 6.7 \mathrm{mg} / \mathrm{l}$; and the mean ESR was $82.5 \pm 26.4 \mathrm{~mm} / \mathrm{h}$. (Table 3) Among the 26 cases, the diagnosis was defined by therapeutic test (11 cases), anatomopathological test (6 cases) and isolation of the microbiological agent (8 cases). (Table 4) Biopsy was performed in $57.7 \%$, only one third of which were assisted by CT. (Table 5 )

The most affected region was the thoracic spine (50\%), and 23 out of the 26 cases (88.4\%) involved had up to 2 levels affected. (Table 6) At the beginning of treatment, neurological status was classified as functional (Frankel D and E) in 16 cases and after 6 months this increased to 22 cases. (Tables 7 and 8) Surgical treatment was required in 9 cases (34.6\%), the main indication being isolated neurological deficit (55.5\%). The most performed procedure was decompression and arthrodesis (55.5\%). In one isolated case, due to failure of the treatment and significant clinical deterioration, drainage of abscesses and collection of new tissue samples were performed. (Figure 1) The mean cure time was $12.0 \pm 8.8$ months (8-48). Complications were observed in 10 cases (38.4\%), the main one being persistent neurological deficit. (Table 8)

Table 1. Sample characteristics - frequencies of sex, age, comorbidities and pulmonary tuberculosis.

\begin{tabular}{c|c}
\hline Variable & Frequency (n) and Percentage (\%) \\
\hline Sample & 26 \\
\hline Sex & $21(80.8 \%)$ \\
\hline Male & $6(19.2 \%)$ \\
\hline Female & $41.6 \pm 22.46(2-77)$ \\
\hline Age & $4(15.3 \%)$ \\
\hline Diabetes mellitus & $1(3.8 \%)$ \\
\hline Chronic kidney disease & $1(3.8 \%)$ \\
\hline Corticosteroid therapy & 0 \\
\hline HIV infection & $2(7.7 \%)$ \\
\hline Active neoplasia & 0 \\
\hline Homeless & $7(26.9 \%)$ \\
\hline Pulmonary tuberculosis &
\end{tabular}

Table 2. Frequencies of signs and signals and time from symptom onset to diagnosis.

\begin{tabular}{c|c}
\hline Variable & Frequency (n) and Percentage (\%) \\
\hline Pain & $22(84.6 \%)$ \\
\hline VAS & $6.85 \pm 2.87$ \\
\hline Fever & $8(30.7 \%)$ \\
\hline Respiratory symptoms & $9(34.6 \%)$ \\
\hline Constitutional symptoms & $14(53.8 \%)$ \\
\hline $\begin{array}{c}\text { Onset of symptoms to diagnosis } \\
\text { (months) }\end{array}$ & $5.5 \pm 5.62(1-24)$ \\
\hline
\end{tabular}

Respiratory symptoms: cough or dyspnea; Constitutional symptoms: weight loss, loss of appetite and night sweats.
Table 3. Mean values of leukocytes, monocyte/lymphocyte ratio, CPR and ESR and frequencies of diagnostic tuberculosis positivity tests.

\begin{tabular}{c|c}
\hline Variable & Values \\
\hline Leukocytes & $7.9 \pm 2.31000 / \mathrm{ml}$ \\
\hline Monocyte/lymphocyte ratio & $0.58 \pm 0.49(0.13-2.44)$ \\
\hline CPR & $5.5 \pm 6.7 \mathrm{mg} / \mathrm{L}$ \\
\hline ESR & $82.5 \pm 26.4 \mathrm{~mm} / \mathrm{h}$ \\
\hline
\end{tabular}

Table 4. Frequency distribution of the tuberculosis diagnosis methods: bacilloscopy (AARB), culture, RMT-TB, anatomopathological testing, therapeutic test, and their respective percentages.

\begin{tabular}{c|c|c}
\hline Variable analyzed & Frequency (n) & Percentage (\%) \\
\hline Culture & 1 & $3.8 \%$ \\
\hline RMT - TB & 2 & $7.7 \%$ \\
\hline Anatomopathological & 6 & $23.0 \%$ \\
\hline Therapeutic test & 12 & $46.1 \%$ \\
\hline AARB, RMT-TB and AP & 1 & $3.8 \%$ \\
\hline Culture, AARB, RMT-TB and AP & 4 & $15.4 \%$ \\
\hline Total & 26 & $100 \%$ \\
\hline
\end{tabular}

AARB: alcohol-acid resistant bacilli, RMT-TB: rapid molecular test for tuberculosis, AP: Anatomopathological testing.

Table 5. Frequencies of biopsies and types performed, surgical cases, reason for indication of surgery, procedure performed, cure time and instrumentation.

\begin{tabular}{|c|c|}
\hline Variable & $\begin{array}{c}\text { Frequency }(\mathrm{n}) \text { and } \\
\text { Percentage }(\%)\end{array}$ \\
\hline Biopsies performed & $15(57.7 \%)$ \\
\hline \multicolumn{2}{|l|}{ Type of biopsy } \\
\hline Conventional & $6(66.6 \%)$ \\
\hline CT-guided & $3(33.3 \%)$ \\
\hline \multicolumn{2}{|l|}{ Treatment } \\
\hline Surgical & $9(34.6 \%)$ \\
\hline Conservative & $17(65.4 \%)$ \\
\hline \multicolumn{2}{|l|}{ Indication } \\
\hline Neurological deficit & $5(55.5 \%)$ \\
\hline Instability & $1(11.1 \%)$ \\
\hline Neurological deficit and instability & $2(22.2 \%)$ \\
\hline Large abscess and failure of clinical treatment & $1(11.1 \%)$ \\
\hline \multicolumn{2}{|l|}{$\begin{array}{l}\text { Procedure } \\
\end{array}$} \\
\hline Abscess drainage & $1(11.1 \%)$ \\
\hline Costotransversectomy/Capener & $3(33.3 \%)$ \\
\hline Decompression and arthrodesis & $5(55.5 \%)$ \\
\hline Instrumentation & $5(55.5 \%)$ \\
\hline Cure time (months) & $12.0 \pm 8.8(8-48)$ \\
\hline Complications & $10(38.4 \%)$ \\
\hline Persistent neurological deficit & 8 \\
\hline Chronic pain & 1 \\
\hline Infection of the surgical site & 1 \\
\hline
\end{tabular}

CT: Computed tomography.

\section{DISCUSSION}

The mean age was between 40 and 50 years, similar to large series. ${ }^{9,24-29}$ Despite what was observed in this study, where most patients were male, there is still no consensus in the literature. ${ }^{25-27}$ Diabetes mellitus was the most frequent comorbidity (15.3\%), higher that that observed in other studies (3.4 to 12.2\%). .,28,29 $^{\text {The others }}$ followed the same pattern, within the range or close to the mean: chronic kidney disease (3.8\%), neoplasia (7.7\%), ranging from 1 to $5 \%$ and around $5 \%$, respectively.

Axial pain was the most common symptom (84\%), similar to that observed in other studies (78-90\%). The mean time from onset of symptoms to diagnosis was 5.5 months, which is similar to other studies, where it is always longer than 3 months. ${ }^{26,27}$ 
According to the literature, fever is not a frequently reported symptom (20-50\%), which was also observed in this study, being the fourth in prevalence (30.7\%). Constitutional (53.8\%) and respiratory (34.6\%) symptoms were greater than the values found in other studies, where they average from $20-30 \%$ and around $10 \%$, respectively. ${ }^{9,26,27,30}$ Laboratory tests are especially useful for diagnosing the insidious evolution of this disease. The main studies indicate that, in at least $70 \%$ of cases, the leukocyte values are normal, while in this study $89.4 \%$ were within the normal reference range. ${ }^{25,31}$ The variation in the relationship between monocytes and lymphocytes in peripheral blood is related to tuberculosis, some types of neoplasia, coronary artery disease, hepatitis B and HIV infection. ${ }^{32}$ The association between this ratio and the development of tuberculosis was first described in 1920 by Florence Sabin in rabbits. ${ }^{33}$ The normal value can vary between 0 and 0.19 , with normal reference values for lymphocytes of 0.9-5.2 $\times$ $10^{9} / \mathrm{L}$ and for monocytes of $0-1 \times 10^{9} / \mathrm{L} .{ }^{34}$ Wang et al. and La Manna et al. observed a mean of 0.36 and a median of 0.50 , respectively. In this study, a mean of 0.58 and a median of 0.46 were found. However, there is still no consensus around the reference value. ${ }^{19,20}$

CT-guided biopsy is considered the gold standard and was performed in $33.3 \%$ of cases. In the only study with a comparable total number of biopsies, they accounted for only $2.8 \%$ of the cases. Perhaps other studies did not publish this data, since practically all cases are conducted this way. ${ }^{29}$

The main site affected was the thoracic spine (50\%), followed by the lumbar spine (46.2\%). The thoracic spine has been generally reported as the most frequent location. However, in the most recent large series, as different from our findings, there was an inversion, with a predominance in the lumbar region. 9,35 Most cases (88.4\%) had up to 2 affected levels, as compared to other series that reported between $67 \%$ and $80 \%$. Around $3.8 \%$ presented non-contiguous level involvement. Yao et al. reported the same finding in $4.5 \%$ of their series of 921 patients. $^{9}$

Table 6. Distribution of the variables analyzed in radiographs, CT and MR.

\begin{tabular}{c|c}
\hline Variable analyzed & Frequency (n) and Percentage (\%) \\
\hline Number of levels affected & $21(80.7 \%)$ \\
\hline 1 & $2(7.7 \%)$ \\
\hline 2 & $1(3.8 \%)$ \\
\hline 3 & $1(3.8 \%)$ \\
\hline 4 & 0 \\
\hline Location & $13(50 \%)$ \\
\hline Cervical & $12(46.2 \%)$ \\
\hline Thoracic & $1(3.8 \%)$ \\
\hline Lumbar & $2(7.7 \%)$ \\
\hline Thoracic and lumbar & $1(3.8 \%)$ \\
\hline 3 or more levels &
\end{tabular}

CT: Computed tomography, MR: Magnetic Resonance.

Table 7. Frequency distribution of initial neurological status and neurological status after 6 months of treatment using the Frankel at al. scale.

\begin{tabular}{c|c|c|c|c|c}
\hline & A & B & C & D & E \\
\hline Initial & $1(3.8 \%)$ & $5(19.2 \%)$ & $4(15.3 \%)$ & $1(3.8 \%)$ & $15(57.6 \%)$ \\
\hline 6 months & - & $1(3.8 \%)$ & $3(11.5 \%)$ & $4(15.3 \%)$ & $18(69.2 \%)$ \\
\hline
\end{tabular}

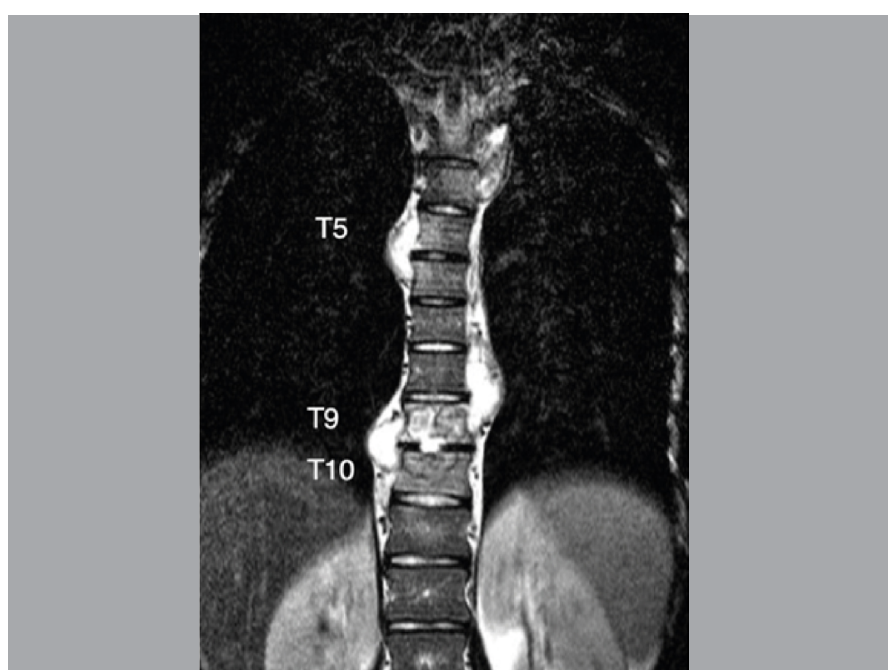

Figure 1. Magnetic resonance coronal cut showing large abscesses. The initial drug treatment failed and there was clinical deterioration. In this case, a decision was made to collect new microbiological samples and drain the abscesses.

Almost all cases with some degree of loss of motor strength (10 out of 11) underwent surgery. The only exception was a patient with severe cardiopathy and not clinically in a condition for surgery. (Table 8)

There was less need for surgical treatment (34.6\%). On average, it ranges from $61-77 \% .{ }^{9,28,29,36}$ The most performed procedure was decompression with arthrodesis at $55.5 \%$, lower than the $75-96 \%$ found in the literature..$^{9,26,29}$ This may be associated with the greater number of cases in our sample with neurological deficit without associated instability, and therefore, not requiring arthrodesis.

The mean prevalence of complications (38.4\%) is within the range reported in other studies, the main one being residual or persistent neurological deficit. Nevertheless, of the 11 patients with some degree of neurological deficit, 10 improved and none worsened during 6 months of follow-up. In the literature, complete neurological recovery is achieved in between 64 and $70 \%$ of cases, ${ }^{29,36}$ while in this series there was full recovery in $27.2 \%$ and partial recovery in $63.6 \%$. The limitations of this study are related to its single-center and retrospective design and to the small sample size. Prospective multicenter studies with longer follow-up can help to understand possible factors for early diagnosis, which today is the biggest challenge in relation to tuberculosis.

\section{CONCLUSION}

Pott's disease is a disease with insidious onset and nonspecific symptoms with a long time from the onset of symptoms to diagnosis, few changes in laboratory examinations, and a high frequency of negative microbiological tests among cases with the disease and imaging examinations with typical characteristics. Few cases required surgical treatment and most cases achieved good neurological recovery.

All authors declare no potential conflict of interest related to this article.

Table 8. Frequencies of neurological deficit at the beginning of treatment, in operated and non-operated cases, and neurological evolution in 6 months (without improvement, partial improvement and complete improvement).

\begin{tabular}{ccccccc}
\hline Frankel & Initial & Surgeries & Conservative & Without improvement & Partial improvement & Complete improvement \\
\hline A & 1 & 1 & - & - & 1 & - \\
\hline B & 5 & 3 & 2 & 1 & 5 & - \\
\hline C & 4 & 3 & 1 & 1 & - & - \\
\hline D & 1 & - & 13 & - & - & - \\
\hline E & 15 & 2 & 17 & 1 & 6 \\
\hline Total & 26 & 9 & & &
\end{tabular}


CONTRIBUTION OF THE AUTHORS: Each author made significant individual contributions to this manuscript. IBZ: writing and data analysis; VLT: writing, data collection; GBK: substantial contribution to the concept and design of the work, writing and data analysis; RM: data analysis and review; MFSC: data analysis, writing and review; AOG: data analysis and review; NA: data analysis and review; RGMM: data analysis and review; MJCS: substantial contribution to the concept and design of the work; TCR: substantial contribution to the concept and design of the work.

\section{REFERENCES}

1. Dean A, Zyck S, Toshkezi G, Galgano M, Marawar S. Challenges in the Diagnosis and Management of Spinal Tuberculosis: Case Series. Cureus. 2019;11(1):1-13. doi: 10.7759/cureus.3855.

2. Wang G, Dong W, Lan T, Fan J, Tang K, Li Y, et al. Diagnostic accuracy evaluation of the conventional and molecular tests for Spinal Tuberculosis in a cohort, head-to-head study. Emerg Microbes Infect. 2018;7: 1-8. doi: 10.1038/s41426-018-0114-1.

3. Mandal N, Anand PK, Gautam S, Das S, Hussain T. Diagnosis and treatment of paediatric tuberculosis: An insight review. Crit Rev Microbiol. 2017;43(4):466-80. doi: 10.1080/1040841X.2016.1262813.

4. Kilborn T, van Rensburg PJ, Candy S. Pediatric and Adult Spinal Tuberculosis. Neuroimaging Clin N Am. 2015;25(2):209-31. doi: 10.1016/..nic.2015.01.002.

5. De la Garza Ramos R, Goodwin CR, Abu-Bonsrah N. The epidemiology of spinal tuberculosis in the United States: an analysis of 2002-2011 data. J Neurosurg Spine. 2016;26(4): 507-12. doi: 10.3171/2016.9.SPINE16174.

6. Kumar K. Spinal tuberculosis, natural history of disease, classifications and principles of management with historical perspective. Eur J Orthop Surg Traumatol. 2016;26(6):551-8. doi: 10.1007/s00590-016-1811-x.

7. Dunn RN, Ben Husien M. Spinal tuberculosis review of current management. Bone Jt J. 2018;100B(4):425-31. doi: 10.1302/0301-620X.100B4.BJJ-2017-1040.R1.

8. Ministério da Saúde. Manual De Recomendações Para O Controle Da Tuberculose No Brasil. 2019 [Acessado em 19 dez 2019]. Disponível em: http://bvsms.saude.gov.br/ bvs/publicacoes/manual_recomendacoes_controle_tuberculose_brasil.pdf

9. Yao Y, Song W, Wang K, Ma B, Liu H, Zheng W, et al. Features of 921 Patients With Spinal Tuberculosis: A 16-Year Investigation of a General Hospital in Southwest China. Orthopedics. 2017;40(6):e1017-23. doi: 10.3928/01477447-20171012-03.

10. Rivas-Garcia A, Sarria-Estrada S, Torrents-Odin C, Casas-Gomila L, Franquet E. Imaging findings of Pott's disease. Eur Spine J. 2013;22:567-78. doi: 10.1007/s00586-012-2333-9.

11. Arockiaraj J, Michael JS, Amritanand R, David KS, Krishnan V. The role of Xpert MTB/ RIF assay in the diagnosis of tubercular spondylodiscitis. Eur Spine J. 2017;26:31629. doi: 10.1007/s00586-017-5076-9.

12. Fucs PMMB, Meves R, Yamada HH. Spinal infections in children: A review. Int Orthop. 2012;36(2):387-95. doi: 10.1007/s00264-011-1388-2.

13. Yao $\mathrm{Y}$, Zhang $\mathrm{H}$, Liu $\mathrm{H}$, Zhang Z, Tang $\mathrm{Y}$, et al. Prognostic Factors for Recovery After Anterior Debridement/Bone Grafting and Posterior Instrumentation for Lumbar Spinal Tuberculosis. World Neurosurg. 2017;104:660-7. doi: 10.1016/j.wneu.2017.05.076.

14. Varatharajah S, Charles YP, Buy X, Walter A, Steib JP. Update on the surgical management of Pott's disease. Orthop Traumatol Surg Res. 2014;100(2):233-9. doi: 10.1016/j. otsr.2013.09.013.

15. Wu W, Lyu J, Liu X, Luo F, Hou TY, Zhou Q, et al. Surgical Treatment of Thoracic Spinal Tuberculosis: A Multicenter Retrospective Study. World Neurosurg. 2018;110: e842-50. doi: 10.1016/j.wneu.2017.11.126.

16. Held MFG, Hoppe S, Laubscher M, Mears S, Dix-Peek S, Zar HJ, et al. High rate of spinal disease in musculoskeletal TB Epidemiology of Musculoskeletal Tuberculosis in an Area with High Disease Prevalence Asian Spine Journal Asian Spine Journal. Asian Spine J. 2017;11(3):405-11. doi: 10.4184/asj.2017.11.3.405.

17. Batirel A, Erdem H, Sengoz G, Pehlivanoglu F, Ramosaco E, Tekin R, et al. The course of spinal tuberculosis (Pott disease): Results of the multinational, multicentre Backbone-2 study. Clin Microbiol Infect. 2015;21(11):1008.e9-1008.e18. doi: 10.1016/j.cmi.2015.07.013.

18. Frankel HL, Hancock DO, Hyslop G, Melzak J, Michaelis LS, Ungar GH, et al. The Value of Postural Reduction in the Initial Management of Closed Injuries of the Spine with Paraplegia and Tetraplegia Part I. Paraplegia. 1969;7(3):179-92. doi: 10.1038/sc.1969.30.

19. La Manna MP, Orlando V, Dieli F, Di Carlo P, Cascio A, Cuzzi G, et al. Quantitative and qualitative profiles of circulating monocytes may help identifying tuberculosis infection and disease stages. PLoS One. 2017;12(2):e0171358. doi: 10.1371/journal. pone. 0171358 .
20. Wang J, Yin Y, Wang X, Pei H, Kuai S, Gu L, et al. Ratio of monocytes to lymphocytes in peripheral blood in patients diagnosed with active tuberculosis. Brazilian $\mathrm{J}$ Infect Dis. 2015;19(2):125-31. doi: 10.1016/j.bjid.2014.10.008

21. Liana P, Brestilova B, Yakub Rahadiyanto K. The ratio of monocytes to lymphocytes accuracy as tuberculosis predictor. J Phys Conf Ser. 2019;1246:012024. doi: $10.1088 / 1742-6596 / 1246 / 1 / 012024$

22. Sae-Jung S, Wongba N, Leurmprasert K. Predictive factors for neurological deficit in patients with spinal tuberculosis. J Orthop Surg. 2019;27(3):1-7. doi: 10.1177/2309499019868813

23. Couto BB, Umeta RSG, Caffaro MFS, Meves R, Landim E, Avanzi O. Análise radiológica comparativa entre espondilodiscite tuberculosa e inespecífica TT. Coluna/Columna. 2010;9(4):394-400. doi: 10.1590/S1808-18512010000400009.

24. Qian J, Rijiepu A, Zhu B, Tian D, Chen L, Jing J, et al. Outcomes of radical debridement versus no debridement for the treatment of thoracic and lumbar spinal tuberculosis. Int Orthop. 2016;40:2081-8. doi: 10.1007/s00264-016-3234-z.

25. Javed G, Laghari AA, Ahmed SI, Madhani S, Shah AA, Najamuddin F, et al. Development of Criteria Highly Suggestive of Spinal Tuberculosis. World Neurosurg. 2018;116:e1002-6. doi: 10.1016/j.wneu.2018.05.149.

26. Yao Y, Zhang H, Liu M, Liu H, Chu T, Tang Y, et al. Prognostic Factors for Recovery of Patients After Surgery for Thoracic Spinal Tuberculosis. World Neurosurg. 2017;105:327-31. doi: 10.1016/j.wneu.2017.05.167.

27. Eroĝlu M, Kaptanoĝlu E, GÖk ŞE, Celikbas A, Baykam N, Dokuuzoguz B. Vertebral osteomyelitis: clinical features and diagnosis. Clin Microbiol Infect. 2014;20(10):1055-60. doi: 10.1111/1469-0691.12653.

28. Liu Z, Wang J, Chen G-Z, et al. Clinical Characteristics of 1378 Inpatients with Spinal Tuberculosis in General Hospitals in South-Central China. Biomed Res Int. 2019;2019:1-11. doi: 10.1155/2019/9765253.

29. Sharma A, Chhabra HS, Chabra T, Mahajan R, Batra S, Sangondimath G. Demographics of tuberculosis of spine and factors affecting neurological improvement in patients suffering from tuberculosis of spine: A retrospective analysis of 312 cases. Spinal Cord. 2017;55(1):59-63. doi: 10.1038/sc.2016.85.

30. Khanna K, Sabharwal S. Spinal tuberculosis: a comprehensive review for the modern spine surgeon. Spine J. 2019;19(11):1858-70. doi: 10.1016/j.spinee.2019.05.002.

31. Yoon YK, Jo YM, Kwon HH, Yoon HJ, Lee EJ, Park SY, et al. Differential diagnosis between tuberculous spondylodiscitis and pyogenic spontaneous spondylodiscitis: A multicenter descriptive and comparative study. Spine J. 2015;15(8):1764-71. doi: 10.1016/j. spinee.2015.04.006.

32. Sibley L, Gooch K, Wareham A, Gray S, Chancellor A, Dowall S, et al. Differences in monocyte: lymphocyte ratio and Tuberculosis disease progression in genetically distinct populations of macaques. Sci Rep. 2019;9(1):2-10. doi: 10.1038/s41598-019-39819-6.

33. Sabin F, Doan C, Cunningham R. Studies of the in Experimental Tuberculosis : the Lymphocyte Ratio; the Anemia-Leucopenia Phase. Trans 22nd Annu Meet Natl Tuberc Assoc 1926;252-6.

34. Djordjevic D, Rondovic G, Surbatovic M, Stanojevic I, Udovicic I, Andjelic T, et al. Neutrophil-to-Lymphocyte Ratio, Monocyte-to-Lymphocyte Ratio, Platelet-to-Lymphocyte Ratio, and Mean Platelet Volume-to-Platelet Count Ratio as Biomarkers in Critically III and Injured Patients: Which Ratio to Choose to Predict Outcome and Nature of Bacteremia? Mediators Inflamm. 2018;3758068. doi: 10.1155/2018/3758068.

35. Shi T, Zhang Z, Dai F, Zhou Q, He Q, Luo F, et al. Retrospective Study of 967 Patients With Spinal Tuberculosis. Orthopedics. 2016;39(5):e838-43. doi: 10.3928/0147744720160509-03.

36. Sharma A, Chhabra HS, Mahajan R, Chabra T, Batra S. Magnetic resonance imaging and genexpert: A rapid and accurate diagnostic tool for the management of tuberculosis of the spine. Asian Spine J. 2016;10(5):850-6. doi: 10.4184/asj.2016.10.5.850. 